\title{
Rumput Laut, Makanan Sehat Abad 21
}

Windu Merdekawati

Program Studi Teknologi Pangan, Fakultas Ilmu Kesehatan, Jl. Kartini No. 11A, Salatiga 50711 (winz.merdekawati18@gmail.com)

Pemanfaatan rumput laut sebagai bahan pangan telah dilakukan sejak jaman dahulu bahkan rumput laut disinyalir telah dikonsumsi sejak jaman manusia purba. Rumput laut umumnya bersifat edible (dapat dimakan). Tumbuhan laut ini kaya akan polisakarida, mineral esensial, vitamin serta protein, rendah kalori dan rendah lemak. Kadar polisakarida dalam rumput laut mencapai 4-76\% dari berat keringnya. Terdapat sekitar 56 jenis mineral dan trace mineral dalam rumput laut. Kadar mineral dalam rumput laut 10-20 kali lebih tinggi daripada mineral dalam tumbuhan darat. Dalam rumput laut juga tersimpan vitamin $A, B, C$, dan D serta vitamin $E$. Rumput laut juga mengandung vitamin $B_{12}$ yang umumnya ditemukan dalam hewan. Kadar protein pada rumput laut mencapai 10-40\% sedangkan kadar lemak hanya berkisar 1-5\% dari berat kering. Jenis lemak dalam rumput laut merupakan PUFA (polyunsaturated fatty acid) khususnya asam lemak omega-3 dan omega-6 yang terkonsentrasi dalam fraksi galaktolipid. Rumput laut telah dimanfaatkan secara tradisional oleh masyarakat Asia dalam pengobatan penyakit kanker, hati dan tiroid; meningkatkan fungsi imun tubuh; sebagai anti-bakteri serta antivirus. Perlunya konsumsi rumput laut dalam menu sehari-hari cukup beralasan mengingat beragam substansi penting serta manfaatnya untuk menunjang dan melindungi kesehatan tubuh.

\section{SEJARAH PEMANFAATAN RUMPUT LAUT}

Rumput laut telah dimanfaatkan sejak ribuan tahun yang lalu. Dalam Icelandic sagas pada abad 10 disebutkan "bangsa Celtic dan bangsa Viking mengunyah dulse sebagai bekal perjalanan mereka". Dulse atau dillisk adalah istilah untuk rumput laut merah jenis Palmaria palmata. Masyarakat Irlandia mulai memanfaatkan rumput laut pada 1200 AD. Dulse dan nori yang dikenal dengan istilah lokal Laver (nama latin untuk tumbuhan laut) menjadi popular di wilayah Irlandia, Wales dan Skotlandia selama berabad-abad. Bladderwrack, Carageen, Badderlock, Sea Lettuce, Sloke dan Tangle adalah spesies lain yang juga telah dikonsumsi oleh bangsa Inggris. 
Di Asia, masyarakat pesisir telah memanfaatkan rumput laut sebagai sumber pangan selama ribuan tahun lamanya. Rumput laut disinyalir telah dikonsumsi masyarakat Cina sejak $2700 \mathrm{BC}$. Bukti mengenai konsumsi rumput laut oleh masyarakat Cina kuno dideskripsikan dalam tulisan Sze Teu pada 600 BC. Dalam tulisannya dikatakan "beberapa jenis rumput laut adalah makanan lezat yang cocok untuk hidangan para tamu agung bahkan juga untuk raja". Enam jenis rumput laut telah digunakan dalam masakan Jepang pada 800 AD dan sampai saat ini ada sekitar 21 jenis yang menjadi menu makanan masyarakat Jepang. Literatur juga menyebutkan penduduk Hawai kuno telah menumbuhkan kebun kelp (ilustrasi pada Gambar 1). Kelp adalah istilah untuk suatu jenis rumput laut coklat dari ordo Laminariales, yang dapat tumbuh membentuk semacam kebun di bawah laut. Terdapat sekitar 40-60 spesies alga laut yang mereka gunakan untuk makanan, obat, upacara adat serta "leis" (karangan bunga).

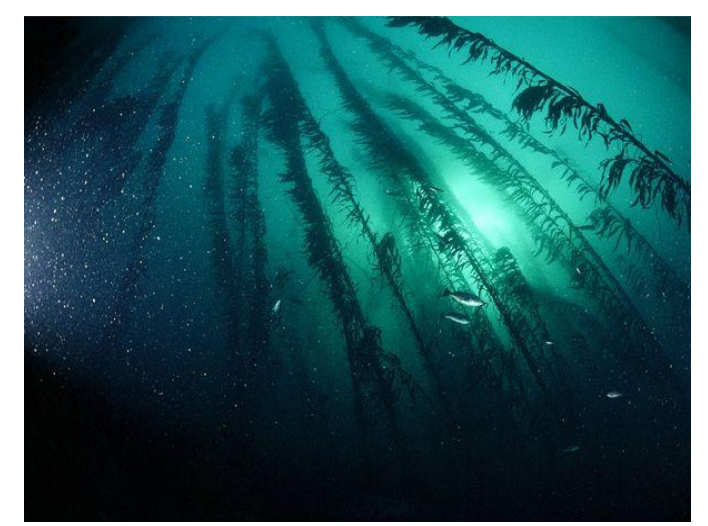

Gambar 1. Kebun kelp di dekat Teluk Bodega, California (sumber:http://ocean.nationalgeographic.com)

Penduduk Tonga telah mengkonsumsi rumput laut coklat yang dikenal dengan istilah "Limu Moui" selama 3000 tahun lebih, hal tersebut dipercaya sebagai resep tradisional untuk menjaga kesehatan dan panjang umur. Di Eropa khususnya wilayah Mediterania, rumput laut telah digunakan sebagai pakan ternak dan obat herbal pada era bangsa Yunani dan Romawi. Bangsa Yunani memanfaatkan rumput laut sebagai makanan hewan pada awal $100 \mathrm{BC}$ dan mulai mengkonsumsinya sebagai makanan pada 46 BC. Dari era pre-Christian di Mediterania, beberapa jenis rumput laut merah telah digunakan sebagai sumber pewarna alami dan sebagai obat cacing (Philpott \& Bradford, 
2006). Di Indonesia, rumput laut mulai dikenal sejak ekspedisi Siboga pada tahun 1899. Rumput laut juga telah dimanfaatkan sebagai makanan dan obat herbal khususnya oleh masyarakat pesisir sejak jaman dahulu. Sebagai makanan tradisional, rumput laut dikonsumsi dalam bentuk sayuran (sup) atau lalapan, jelly, serta campuran kue tradisional. Melengkapi khasanah kearifan lokal masyarakat pesisir, rumput laut juga telah lama dimanfaatkan sebagai obat tradisional untuk mengatasi penyakit yang terkait dengan masalah pencernaan (lambung), penyakit gondok, serta sebagai obat cacingan (Anggadireja et al., 1996; Atmadja et al., 1996). Beragam manfaat rumput laut tak lepas dari berbagai substansi yang tersimpan di dalamnya.

\section{KOMPOSISI NUTRIEN DALAM RUMPUT LAUT}

\section{Polisakarida}

Polisakarida merupakan komponen utama penyusun rumput laut. Total polisakarida yang terkandung dalam rumput laut bervariasi tergantung spesies, dengan kisaran antara 4-76\% dari berat kering. Berdasarkan jenis polisakarida, rumput laut dikelompokkan menjadi 3 yaitu agarofit, karaginofit, dan alginofit. Agarofit adalah kelompok rumput laut penghasil agar. Secara kimia, agar terdiri dari dua komponen, yaitu agarosa dan agaropektin. Komponen utamanya adalah agarosa yang merupakan polimer netral dengan unit primer berupa disakarida agarobiosa. Agaropektin merupakan campuran polisakarida yang terdiri dari(1,3)- $\beta$-D-galaktopiranosa dan residu (1,4)-3,6-anhidro- $\alpha$-L-galakto-piranosa. Rumput laut penghasil agar diantaranya: Gracilaria, Gelidium, Gelidiopsis, dan Hypnea, yang termasuk jenis rumput laut merah (Gambar 2).
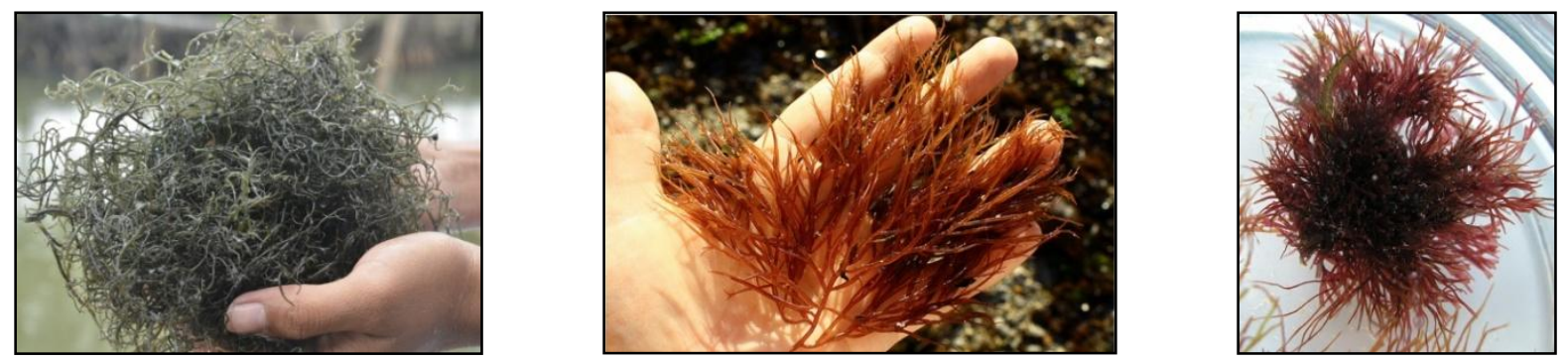

Gambar 2. Contoh agarofit: Gracilaria sp. (kiri), Gelidium sp. (tengah), dan Gelidiopsis sp. (kanan) (sumber : wwf.or.id) 
Polisakarida lainnya yang juga dihasilkan rumput laut merah adalah karaginan (Gambar 3). Karaginan merupakan senyawa hidrokoloid yang terdiri dari ester kalium, natrium, magnesium, dan kalsium sulfat dengan galaktosa dan 3,6 anhidrogalaktosa. Chaplin (2005) menyebutkan, terdapat tiga jenis karaginan yaitu kappa ( $\kappa)$, iota (1) dan lambda $(\lambda)$ karaginan. Kappa karaginan terdiri dari unit (1,3)- $\beta$-D-galaktosa-4-sulfat dan (1,4)-3-6-anhidro- $\alpha$-D-galaktosa, hanya mengandung satu gugus sulfat pada struktur molekulnya. Sumber kappa karaginan ialah rumput laut merah jenis Kappaphycus alvarezii. Iota karaginan terdiri dari unit (1,3)- $\beta$-D-galaktosa-4-sulfat dan $(1,4)-3-6$-anhidro- $\alpha$-D-galaktosa-2-sulfat, mempunyai dua gugus sulfat pada struktur molekulnya. Iota karaginan dapat diekstrak dari rumput laut merah jenis Eucheuma spinosum. Lambda karaginan tersusun oleh unit yaitu $(1,3)-\beta$-D-galaktosa-4-sulfat dan (1,4)-3-6-anhidro- $\alpha$-D-galaktosa-2,6-disulfat, terdapat tiga gugus sulfat pada struktur molekulnya. Lambda karaginan terdapat pada rumput laut merah jenis Chondrus crispus. Semua jenis rumput laut penghasil karaginan tersebut dikelompokkan dalam karaginofit.
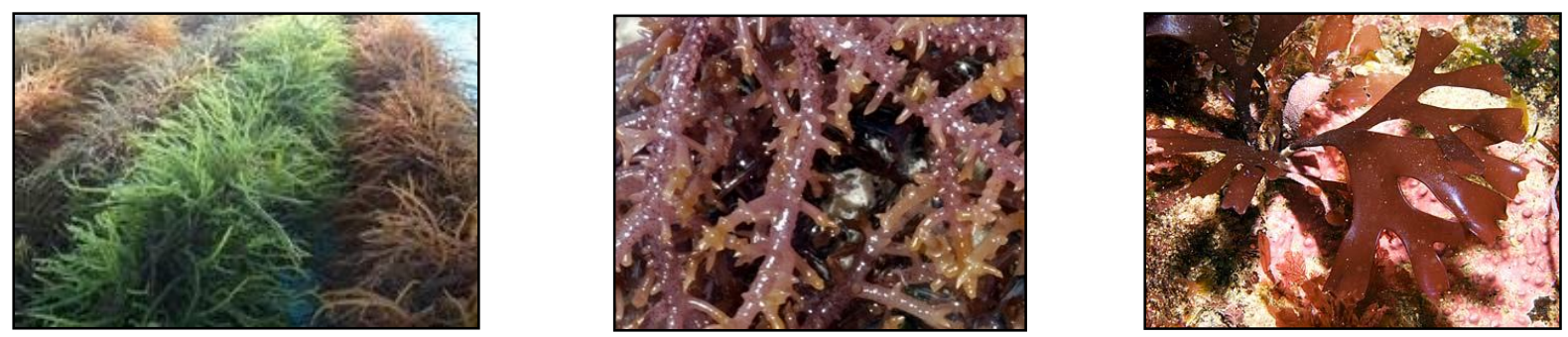

Gambar 3. Karaginofit : Kappaphycus alvarezii (kiri), Eucheuma spinosum (tengah), dan Chondrus crispus (kanan) (sumber: http://www.habitas.org.uk)

Polisakarida lainnya yaitu alginat yang banyak terdapat pada rumput laut coklat. Rumput laut coklat yang potensial menghasilkan alginat umumnya tumbuh di perairan subtropis, jenisnya antara lain: Macrocystis, Laminaria, Aschophyllum, Nerocystis, Ecklonia, Fucus dan Sargassum. Rumput laut coklat yang tumbuh di perairan tropis termasuk di Indonesia adalah jenis Sargassum, Turbinaria Padina, dan Dictyota (Gambar 4). Semua jenis rumput laut tersebut dikelompokkan dalam alginofit (rumput laut penghasil alginat). Alginat atau algin adalah suatu senyawa yang terkandung dalam 
dinding sel rumput laut coklat (Phaeophyceae) yang merupakan komponen utama selain pektin dan selulosa.
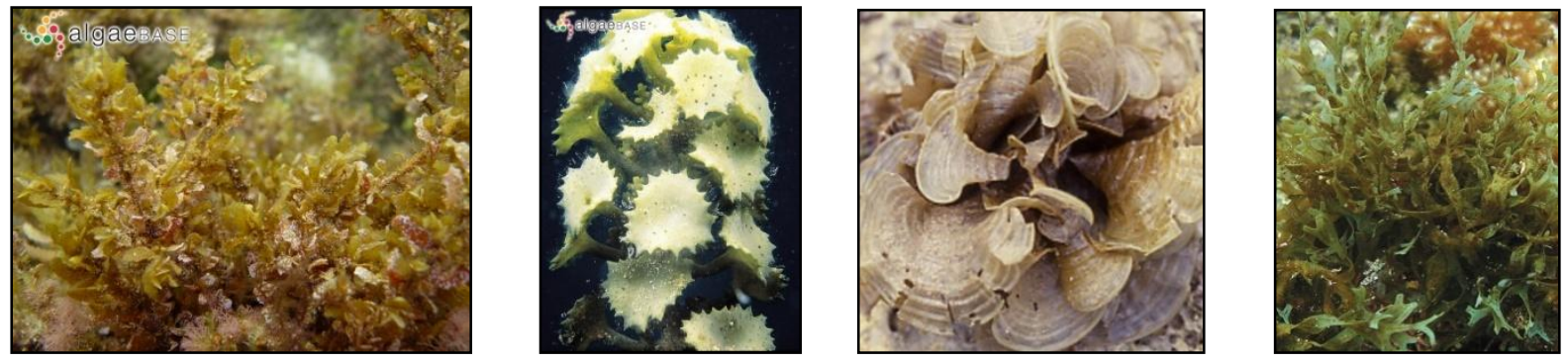

Gambar 4. Alginofit: secara berurutan dari kiri - kanan Sargassum polycystum, Turbinaria ornata, Padina australis, dan Dictyota cervicornis (sumber:www.images.algaebase.org)

Secara kimia alginat merupakan polimer murni dari asam uronat yang tersusun dalam bentuk rantai linear yang panjang. Senyawa alginat merupakan suatu polimer organik polisakarida yang terdiri dari tiga macam struktur $\alpha-1,4-\mathrm{L}$ guluronat, $\beta-1,4-\mathrm{D}$ mannuronat dan selang-seling keduanya. Asam alginat dapat berupa homopolimer yang terdiri dari monomer sejenis yaitu asam D-mannuronat saja atau asam L-guluronat saja (Winarno, 1996; Yunizal, 2004). Homopolimer dari asam D-mannuronat (asam polimannuronat) dibentuk dari pengulangan asam D-mannuronat dengan ikatan $\alpha-(1,4)$ dan ikatan hidrogen antara gugus hidroksil pada atom C3 dengan atom oksigen pada cincin heksosa yang berdekatan. Bentuk homopolimer dari asam L-guluronat lebih kaku daripada homopolimer asam D-mannuronat. Alginat dengan proporsi poliguluronat yang tinggi cenderung membentuk gel yang kaku, regas, sedangkan alginat dengan proporsi polimannuronat lebih tinggi akan membentuk gel yang lebih elastis, kurang regas (Yunizal, 2004).

\section{Vitamin dan Mineral}

Rumput laut kaya akan vitamin $\mathrm{A}, \mathrm{B}_{1}, \mathrm{~B}_{2}, \mathrm{~B}_{3}, \mathrm{~B}_{9}$ dan vitamin E. Vitamin $\mathrm{C}$ dan vitamin E merupakan antioksidan potensial, sedangkan vitamin A berperan penting dalam perkembangan dan diferesiansi sel. Rumput laut kaya akan yodium, zat besi, potasium, magnesium, kalsium, selenium dan fosfor. Rumput laut mengandung 56 jenis mineral dan trace-mineral penting bagi tubuh. Mineral yang merupakan komponen utama dalam suplemen. Tumbuhan laut yang melimpah ini merupakan sumber mineral 
alternatif selain dari sumber nabati (tumbuhan darat) dan sumber hewani (daging, telur, susu) yang penting bagi tubuh. Kappaphycus alvarezii mengandung ion magnesium dan kalsium dalam kadar tinggi, masing-masing yaitu 581,20 mg/L dan 460,11 mg/L. Iodin berperan penting dalam menunjang fungsi tiroid. Magnesium penting dalam penyerapan kalsium, zat besi berperan dalam pertukaran oksigen dalam darah.

\section{Protein dan Lemak}

Kadar protein dalam tumbuhan laut terdapat dalam jumlah yang cukup signifikan, hingga dapat mencapai 48\% (Tabel 2). Sebaliknya, kadar lemak dalam rumput laut hanya berkisar antara 1-5\% dari berat kering. Walaupun demikian, lemak terdapat dalam komposisi asam lemak tak jenuh, khususnya asam lemak omega-3 dan omega-6 yang berada dalam bentuk fraksi galaktolipid. Jenis asam lemak lainnya yaitu asam stearidonik dan asam heksadekatetraenoik yang terdapat dalam kadar tinggi (mencapai 40\%) pada rumput laut jenis Undaria spp. dan Ulva spp. Galaktolipid termasuk sulphoquinovosyldiacylglyceride (SQDG) ditemukan dalam alga coklat jenis Undaria spp. dan Laminaria spp. Rumput laut hijau mengandung asam alfa linoleat ( $\omega-3, \mathrm{C} 18: 3)$. Turunan teroksigenasi asam lemak (termasuk eicosanoid) juga ditemukan dalam rumput laut merah. Eicosanoid berperan dalam mengatur diferensiasi sel, respon imun dan mengatur homeostatis.

\section{Senyawa Bioaktif serta Polisakarida Lainnya}

Rumput laut juga kaya akan senyawa bioaktif serta pigmen yang sangat bermanfaat bagi kesehatan. Rumput laut mempunyai beberapa senyawa yang berpotensi sebagai antioksidan di antaranya yaitu karotenoid $(\alpha$ - dan $\beta$-karoten, fukoxantin), MAA (mycosporine-like amino acids) dan taurin, katekin (epigalokatekin, epigalokatekin gallate), phlorotannins (phloroglucinol, eckol) dan tokoferol (Burtin, 2003).

Senyawa fukoidan yang terdapat pada rumput laut, mampu meningkatkan imunitas dengan merangsang produksi sel-sel imun. Senyawa ini juga membantu melawan virus dan bakteri, alergi, dan menghambat penggumpalan darah, sehingga memperkecil resiko stroke dan serangan jantung. Senyawa tersebut juga dapat 
menurunkan kadar kolesterol darah dan tekanan darah tinggi, menstabilkan kadar gula (glukosa) darah dengan memperlambat pelepasan glukosa ke dalam darah, meredakan gangguan pencernaan dengan mencegah masuknya bakteri Helicobacter pylori, meningkatkan fungsi hati, menjaga kelembaban dan kekencangan kulit, serta menghambat pertumbuhan sel abnormal.

Komposisi pigmen yang khas pada rumput laut juga menambah nilai manfaat tumbuhan ini. Penelitian di Hokkaido University menemukan adanya potensi antiobesitas dari pigmen fukoxantin pada rumput laut coklat (Maeda et al., 2005). Selain itu berbagai jenis pigmen pada rumput laut juga bermanfaat sebagai antioksidan, antikanker dan antitumor. Pigmen alami dapat digunakan sebagai pewarna alternatif yang aman bagi kesehatan.

\section{RUMPUT LAUT DAN ANEKA PRODUK OLAHANNYA}

Rumput laut telah dimanfaatkan sebagai bahan pangan sejak lama. Jepang, Korea dan Cina merupakan negara pengkonsumsi rumput laut terbesar di dunia. Sekitar 25\% dari makanan yang dikonsumsi orang Jepang mengandung rumput laut yang disimpan dan disajikan dalam beragam olahan, seperti sebagai berikut:

\section{Nori}

Nori terbuat dari rumput laut merah jenis Porphyra sp. Nori berbentuk lembaran tipis dan kering. Olahan rumput laut ini merupakan bahan baku untuk membuat sushi, onigiri dan sebagai topping untuk berbagai masakan mie dan masakan lain di Jepang.

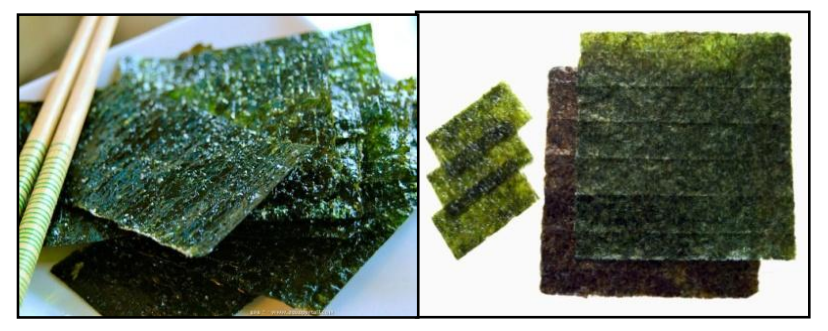

Gambar 5. Nori (Sumber : http://www.aquaportail.com) 


\section{Wakame}

Wakame berasal dari Undaria sp., salah satu spesies rumput laut coklat. Wakame biasa digunakan dalam sup diantaranya sup miso dan salad sunomono. Wakame dijual dalam bentuk kering dan harus direndam dalam air sebelum digunakan.

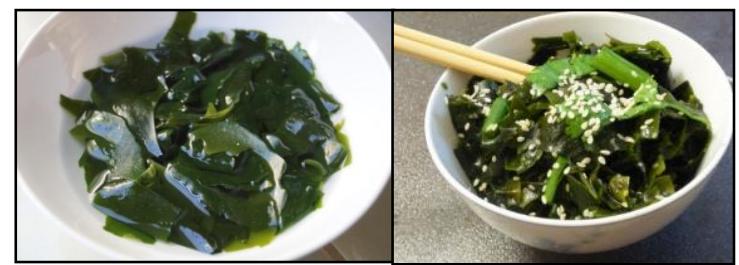

Gambar 6. Wakame (Sumber : http://www.japanesecooking101.com)

\section{Kombu}

Kombu merupakan produk Laminaria sp. dan beberapa jenis rumput laut coklat yang dapat dikonsumsi di Jepang. Kombu terbagi atas tiga kualitas yaitu kombu hijau (kizami), kombu hitam (kurotororo) dan kombu putih (shirotororo). Kombu biasa digunakan dalam sup atau dalam masakan nabe (hot pot) di Jepang.

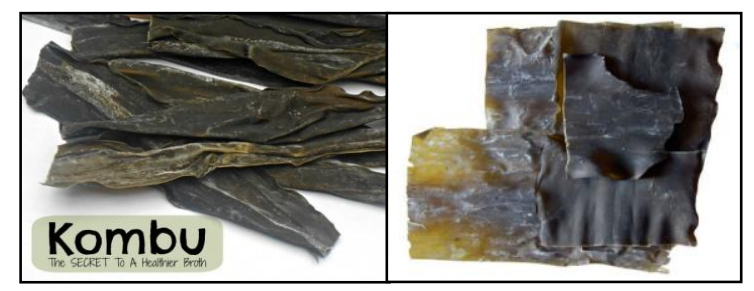

Gambar 7. Kombu (Sumber: http://theantidotelife.com)

\section{Dulse}

Rumput laut merah jenis Palmaria palmata atau yang sering dikenal dengan "dulse" banyak dikonsumsi oleh masyarakat di wilayah Irlandia. Rumput laut berwarna ungu dan bertekstur lembut. Dulse mempunyai kadar zat besi yang tertinggi dibandingkan jenis tumbuhan laut lainnya. Kadar zat besi dalam Dulse 10-20 kali lebih banyak daripada zat besi dalam bayam. Dulse banyak dikonsumsi secara langsung sebagai sayuran atau lalapan serta dikonsumsi dalam bentuk kering.

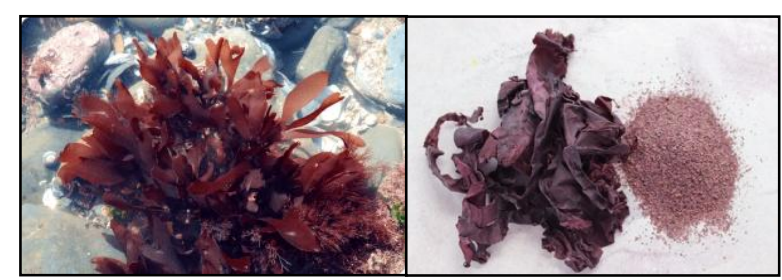

Gambar 8. Dulse (Palmaria palmata) (Sumber :http://www.asianhealthsecrets.com) 
Tabel 1. Jenis Rumput Laut Edibel

\begin{tabular}{|c|c|c|}
\hline KELAS & GENUS & NAMA LOKAL \\
\hline $\begin{array}{l}\text { Rumput Laut Coklat } \\
\text { (Phaeophyceae) }\end{array}$ & $\begin{array}{l}\text { Alaria } \\
\text { Himanthalia/Bifurcaria } \\
\text { Laminaria } \\
\text { Saccharina } \\
\text { Undaria } \\
\text { Ascophyllum } \\
\text { Fucus } \\
\text { Sargassum } \\
\text { Hizikia } \\
\text { Sargassum } \\
\text { Dictyotales } \\
\text { Eisenia }\end{array}$ & $\begin{array}{l}\text { Kelp/bladderlocks } \\
\text { Sea spaghetti, fucales } \\
\text { Kelp/kombu/kumbu/sea tangle } \\
\text { Sugar wrack } \\
\text { Wakame } \\
\text { Egg wrack } \\
\text { Bladder wrack, rockweed } \\
\text { Mojaban/Indian brown seaweed } \\
\text { Hijiki } \\
\text { Sea holly } \\
\text { Arame }\end{array}$ \\
\hline $\begin{array}{c}\text { Rumput Laut Merah } \\
\text { (Rhodophyceae) }\end{array}$ & $\begin{array}{l}\text { Rhodymenia/Palmaria } \\
\text { Porphyra } \\
\text { Chondrus } \\
\text { Mastocarpus/Gigartina } \\
\text { Gracilaria } \\
\text { Asparagopsis } \\
\text { Grateloupia } \\
\end{array}$ & $\begin{array}{l}\text { Dulse } \\
\text { Nori/haidai/gim } \\
\text { Irish moss/carrigen } \\
\text { Stackhouse, Guiry } \\
\text { Limu Kobu }\end{array}$ \\
\hline $\begin{array}{l}\text { Rumput Laut Hijau } \\
\text { (Chlorophyceae) }\end{array}$ & Ulvaria/Enteromorpha & Laver/sea lettuce/sea grass/nori \\
\hline
\end{tabular}

Tabel 2. Perbandingan Analisis Nutrisi Rumput Laut Edibel dengan Sumber Nutrisi Lainnya

\begin{tabular}{|c|c|c|c|c|c|c|c|c|}
\hline \multirow{2}{*}{$\mathrm{gr} / 100 \mathrm{gr}$} & \multirow{2}{*}{$\begin{array}{c}\text { FIBRE } \\
\text { NSP }\end{array}$} & \multirow{2}{*}{ AIR } & \multirow{2}{*}{ PROTEIN } & \multirow{2}{*}{ LEMAK } & \multirow{2}{*}{ KARBOHIDRAT } & \multirow{2}{*}{ MINERAL } & \multicolumn{2}{|c|}{ ENERGI } \\
\hline & & & & & & & Kcal & $\mathbf{K j}$ \\
\hline Nori & 4,7 & 5,1 & 35,6 & 0,6 & 46,3 & 1,03 & 349 & 1,483 \\
\hline Arame & 1,1 & 11,5 & 12 & 0,2 & 68,1 & 6,36 & 313 & 1,328 \\
\hline Dulse & 1,2 & 13,8 & 7,9 & 0,1 & 59,8 & 9,20 & 272 & 1,155 \\
\hline Kombu & 3,0 & 18,2 & 7,3 & 0,3 & 61,6 & 7,27 & 274 & 1,165 \\
\hline Wakame & 3,6 & 16,3 & 17,3 & 0,7 & 39,0 & 9,17 & 232 & 983 \\
\hline Hijiki & 17 & 6,2 & 10 & 0,1 & 56,8 & 6,50 & 260 & 1.104 \\
\hline Agar-agar & 0 & 20,6 & 1,9 & 0,4 & 73,7 & 3,40 & 306 & 1.300 \\
\hline Bayam & 2,1 & 89,7 & 2,8 & 0,8 & 1,6 & 0,91 & 25 & 103 \\
\hline Brokoli & 2,6 & 88,2 & 4,4 & 0,9 & 1,8 & 0,54 & 33 & 138 \\
\hline Wortel & 2,4 & 88,8 & 0,7 & 0,5 & 6,0 & 0,34 & 30 & 125 \\
\hline Whole milk & 0 & 87,6 & 3,3 & 3,9 & 4,5 & 0,42 & 66 & 274 \\
\hline Jeruk & 1,7 & 86,1 & 1,1 & 0,1 & 8,5 & 0,23 & 37 & 158 \\
\hline Susu skim & 0 & 3,0 & 36,1 & 0,6 & 52,9 & 4,50 & 348 & 1482 \\
\hline Daging & 0 & 71,9 & 22,5 & 4,3 & 0 & 0,64 & 129 & 542 \\
\hline
\end{tabular}


Jl. Diponegoro No. 52 - 60, Salatiga - Jawa Tengah 50711

Telp. (0298) 321212 (Ext. 441) / (+62) 85640203075, Fax. (0298) 329200 E-Mail: bios.uksw@gmail.com / Website: www.biozmagz.com

Tabel 3. Perbandingan Analisis Nutrisi Rumput Laut Edibel Berdasarkan Kandungan Mineral dan Vitamin

\begin{tabular}{|l|c|c|c|c|c|c|c|c|}
\hline \multicolumn{1}{|c|}{ Per 100 gr } & $\begin{array}{c}\text { Kalsium } \\
\text { (mg) }\end{array}$ & $\begin{array}{c}\text { Zat besi } \\
\text { (mg) }\end{array}$ & $\begin{array}{c}\text { Iodin } \\
\text { (mg) }\end{array}$ & $\begin{array}{c}\text { Potasium } \\
\text { (mg) }\end{array}$ & $\begin{array}{c}\text { Vit A } \\
\text { IU }\end{array}$ & $\begin{array}{c}\text { Vit B1 } \\
\text { (mg) }\end{array}$ & $\begin{array}{c}\text { Vit B2 } \\
\text { (mg) }\end{array}$ & $\begin{array}{c}\text { Vit C } \\
\text { (mg) }\end{array}$ \\
\hline Nori & 470 & 23 & 1 & 3.505 & 11.000 & 0,25 & 1,24 & 20 \\
Arame & 1170 & 12 & 300 & 3.860 & 50 & 0,02 & 0,20 & 0 \\
Dulse & 296 & 150 & 150 & 8.060 & 188 & 0,63 & 0,50 & 30 \\
Kombu & 800 & 15 & 300 & 5.800 & 430 & 0,08 & 0,32 & 11 \\
Wakame & 1300 & 13 & 25 & 6.800 & 140 & 0,11 & 0,14 & 15 \\
Hijiki & 1400 & 29 & 40 & 14.700 & 150 & 0,01 & 0,2 & 0 \\
Agar-agar & 400 & 5 & 0 & - & 0 & 0 & 0 & 0 \\
Bayam & 170 & 2,1 & 0,002 & 500 & & 0,07 & 0,09 & 26 \\
Brokoli & 56 & 1,7 & 0,002 & 370 & & 0,1 & 0,06 & 87 \\
Wortel & 34 & 0,4 & 0,002 & 240 & 12036 & 0,04 & 0,02 & 4 \\
Jeruk & 47 & 0,1 & 0,002 & 150 & 247 & 0,11 & 0,04 & 54 \\
Whole milk & 118 & 0,03 & 0,031 & 155 & 490 & 0,03 & 0,23 & 2 \\
Susu skim & 1280 & 0,27 & 0,15 & 1590 & 122 & 0,38 & 1,63 & 13 \\
Daging mentah & 5 & 2,7 & 0,01 & 350 & 0 & 0,1 & 0,21 & 0 \\
\hline
\end{tabular}

\section{PENUTUP}

Berbagai penelitian menunjukkan potensi rumput laut sebagai sumber pangan penting. Tidak mengherankan jika saat ini dunia sedang booming makan rumput laut. Beragam cara dilakukan untuk menyertakan rumput laut dalam menu makanan karena tumbuhan yang kini dijuluki sebagai "super food" ini dipercaya tidak hanya mengenyangkan tetapi juga menyehatkan tubuh. Semoga di negeri yang dikenal sebagai salah satu penghasil rumput laut terbesar di dunia ini tren makan rumput laut juga semakin meningkat. Rumput laut potensial sebagai solusi pangan cerdas untuk ikut berperan dalam menjaga kestabilan pangan, menunjang kesehatan serta meningkatkan kesejahteraan masyarakat.

"Lets go blue Indonesia!"

\section{BIBLIOGRAFI}

Atmadja, W. S., A. Kadi, Sulistijo \& R. Satari. 1996. Pengenalan Jenis-Jenis Rumput Laut Indonesia. Jakarta : Puslitbang Oseanologi-LIPI.

Burtin, P. 2003. Nutritional Value of Seaweeds. Electronic Journal of Environmental Agricultural and Food Chemistry, 2 (4), 498-503

Chaplin, M. 2005. Carageenan. (http://www.lsbu.ac.uk/water/hycar.html) 
Jiménez-Escrig, A.; Sánchez-Muniz, F.J. 2000. Dietary Fibre fFrom Edible Seaweeds: ChemicalStructure, Physicochemical Properties and Effects on Cholesterol Metabolism. Nutrition Research, 20, 585-598. Maeda, H., Hosokawa, M., Sashima, T., Murakami-Funayama, K., Miyashita, K. 2008. Anti-Obesityand AntiDiabetic Effects of Fucoxanthin on Diet-Induced Obesity Conditions in a Murine Model. Mol. Med. Rep. 2: 897-902.

Philpott, J \& Bradford, M. 2006. Seaweed: Nature's Secret for a Long and Healthy Life? The Nutritionist Practitioner.

Winarno, F.G. 1996. Teknologi Pengolahan Rumput Laut. Pustaka Harapan. Jakarta.

Yunizal. 2004. Teknologi Pengolahan Alginat. Pusat Riset Pengolahan Produk dan Sosial Ekonomi Kelautan dan Perikanan. BRKP, Jakarta, 66 hlm. 